\title{
VEGETATION RESPONSES TO 35 AND 55 YEARS OF NATIVE UNGULATE GRAZING IN SHRUBSTEPPE COMMUNITIES
}

\author{
Echo A. Rexroad ${ }^{1}$, Karen H. Beard ${ }^{1,2}$, and Andrew Kulmatiski ${ }^{1}$
}

\begin{abstract}
Aвstract.-Ungulate populations are managed in shrubsteppe ecosystems around the world, but relatively few long-term datasets are available that test the impacts of these grazers on shrubsteppe structure and function. This study evaluated 8 exclosures in 4 shrubsteppe communities to determine the effects of deer and elk over 35 or 55 years on (1) plant biomass and species composition, $(2)$ soil nitrogen $(\mathrm{N})$ mineralization and net nitrification rates, Olsen extractable phosphorus $(\mathrm{P})$, and $\mathrm{C}: \mathrm{N}$ ratios, and (3) arthropod diversity and abundance. The site with deer, the highest ungulate densities, and coldest climate (Sinlahekin Wildlife Area, WA) had greater vegetative biomass and cover inside the exclosures than outside. The sites with elk, moderate ungulate densities, and intermediate climatic conditions (Oak Creek and Wenas Wildlife Areas, WA) had no effects of exclosures on vegetative biomass or cover. The site with elk, the lowest ungulate densities, and driest climatic conditions (L.T. Murray Wildlife Area, WA) had greater shrub cover outside of the exclosures. Ungulates significantly increased net $\mathrm{N}$ mineralization and nitrification rates, providing a potential explanation for compensatory growth by grazed plants. Our data suggest that arthropod herbivory does not substitute for ungulate herbivory. To the contrary, arthropod diversity reflected ungulate-induced changes in plant biomass. In addition to effects on standing biomass, ungulates were associated with increased exotic plant species richness at all 4 sites. Our results suggest that there may be a balance between indirect positive and direct negative effects of herbivory on plants that varies with ungulate densities and site characteristics, and that arthropod herbivory does not functionally replace ungulate herbivory.
\end{abstract}

Key words: shrubsteppe, ungulate, vegetation, arthropod, C:N ratios, nitrogen mineralization, net nitrification, soilavailable phosphorus.

Native ungulates influence plant growth directly through consumption and trampling of aboveground plant parts, and indirectly through shifts in apparent competition and increased nutrient cycling rates (Hobbs 1996). Ungulates influence nutrient cycling rates through 2 main mechanisms. Ungulate herbivory converts plant-bound carbon $(\mathrm{C})$ and nitrogen $(\mathrm{N})$ into forms that are more available to plants and soil microorganisms, a process called the fertilization effect (Frank and Groffman 1998, Wardle 2002). Grazing also stimulates a reallocation of plant $\mathrm{C}$ reserves to aboveground growth (Tracy and Frank 1998, Johnson and Matchett 2001). This reallocation decreases root exudation of soluble $\mathrm{C}$ and, therefore, microbial demand for $\mathrm{N}$; this can free $\mathrm{N}$ for plant uptake (Hobbs 1996, Frank and Groffman 1998). Models attempting to explain these interactions often underemphasize the potential for ungulates to have fertilization effects (e.g., Milchunas et al. 1988). Studies that do account for the potential of ungulates to increase nutrient cycling rates often overlook long-term native ungulate effects on shrubsteppe ecosystems (e.g., Hobbs 1996, Frank and Groffman 1998) or lack a field component to test their hypotheses (e.g., DeMazancourt et al. 2001).

However, the relative importance of these impacts and the response of vegetation and soil properties to native ungulates are often ecosystem-specific (Milchunas and Lauenroth 1993). Thus, it is necessary to determine the role of native ungulates in shrubsteppe ecosystems because ungulates are presently being managed similarly in different ecosystems (Porter and Underwood 1999). Only a small proportion of long-term studies on ungulate influences have been on native ungulates, the majority of which came from grassland ecosystem types (Milchunas and Lauenroth 1993). Additionally, in studies that have focused on shrubsteppe ecosystems, the average time for ungulate exclusion was 20 years. Thus, few studies have evaluated the communityand ecosystem-level impacts of large native

\footnotetext{
${ }^{1}$ Department of Forest, Range and Wildlife Sciences, and the Ecology Center, Utah State University, Logan, UT 84322-5230.

${ }^{2}$ Corresponding author. E-mail: karen.beard@usu.edu
} 
ungulates in a shrubsteppe ecosystem for a period longer than 20 years (Milchunas and Lauenroth 1993).

Many field studies on ungulate effects are conducted using exclosures. When ungulates are excluded from an ecosystem, their effects on vegetation could be masked if there is herbivore substitution. Herbivorous arthropods, for example, could play a functional role similar to ungulates; however, the substitution of grazer functions by arthropods is rarely considered in herbivory studies. Rather, it is often assumed that ungulates have the greatest influence on arthropods through changes in vegetation structure and composition (Stewart 2001). However, approximately 75\% of arthropods are phytophagous (Lawton and Strong 1981, Rambo and Faeth 1999), and an increase in vegetative quantity (e.g., biomass and cover) following ungulate removal should increase arthropod abundance and potentially arthropod diversity. In addition, if ungulate removal reduces the number of exotic plant species, this should increase the diversity of arthropods and potentially herbivory (Samways et al. 1996).

The objectives of this study were to determine the effects of either native deer (Odocoileus hemionus hemionus and O. virginianus ochrourus) or elk (Cervus canadensis nelsoni) grazing over 35 and 55 years in 4 shrubsteppedominated wildlife areas located in central Washington State. More specifically, using existing ungulate exclosures, we determined the effects of either deer or elk on (1) vegetative structure and composition (e.g., biomass, percent cover, and species richness), (2) soil properties such as $\mathrm{N}$ mineralization, net nitrification, bicarbonate-extractable phosphorus $(\mathrm{P})$, C:N ratios, and soil moisture, and (3) arthropod diversity and abundance.

\section{STUdy SiTES}

The 8 exclosures in this study are located in central Washington (Table 1). Comparison plots were established directly adjacent to each exclosure. Mean annual precipitation was greatest and mean annual temperature was lowest at the Sinlahekin Wildlife Area; mean annual precipitation was lowest at the Oak Creek and Wenas Wildlife Areas; and mean annual temperature was highest at the L.T. Murray Wildlife Area (Table 1). These patterns in temperature and precipitation were reflected in the vegeta- tion found at each site and support the wellestablished correlation between productivity and water availability in arid systems (Semmartin et al. 2004). Ponderosa pine (Pinus ponderosa P. \& C. Lawson) was only present at the coolest and wettest site (Sinlahekin). At the drier Oak Creek site, we found smaller trees and shrubs, such as Prunus virginiana L. (Nutt.), Amelanchier Medik., and Purshia tridentata (Pursh) DC. No trees were observed at L.T. Murray or Wenas.

Whitetail and mule deer were the dominant ungulates at the Sinlahekin Wildlife Area; however, moose (Alces alces) and bighorn sheep (Ovis canadensis) were occasionally observed. Elk were the dominant ungulates in the Oak Creek, Wenas, and L.T. Murray Wildlife Areas, although bighorn sheep have been occasionally observed in the Oak Creek and Wenas Wildlife Areas, and mule deer have been found in the L.T. Murray Wildlife Area. The L.T. Murray and Oak Creek Wildlife Areas have maintained an annual winter feeding program for elk since 1964 and 1945, respectively. Other than by trespass, livestock have not grazed in these areas since the early 1980s (W. Hunt, D. Kuehn, J. McGowen, and D. Swedberg personal communication).

\section{Methods \\ Vegetation}

Near the end of the growing season in June 2003, plant abundance (percent ground cover), height, biomass, and species richness were estimated along four 30.5-m or 61-m transects inside and 4 transects outside the exclosures. Measurements were recorded at 5-m intervals in $1 \times 1-\mathrm{m}$ quadrats for a total of 5 or 10 quadrats along each $30.5-\mathrm{m}$ or $61-\mathrm{m}$ transect, respectively. Transect lengths varied with the size of the original exclosure (Table 1). Percent cover of plant species, litter, bare soil, and rock was determined for 81 points along a regularly spaced $9 \times 9$ grid in each quadrat. Vegetation height was measured at 16 randomly selected points within each quadrat. To determine biomass, we used a comparative yield method similar to Haydock and Shaw (1975). Every quadrat was described using a biomass category that ranged from bare soil (0) to thick shrub understory or tree overstory (6) in increments of $0.5(0,0.5,1,1.5$, and so forth). 


\section{Soil Properties}

In May 2003 we extracted 10 paired soil cores from both inside and outside each exclosure for a total of 40 cores per exclosure to determine net $\mathrm{N}$ mineralization and net nitrification rates using the buried bag technique (Robertson et al. 1999). We stratified sampling locations by dominant vegetation type (i.e., grass, shrub, or no vegetation). Total $\mathrm{C}$, total $\mathrm{N}$, and bicarbonate-extractable $\mathrm{P}$ were determined from preincubation soil samples $(n=$ 10 inside and $n=10$ outside each exclosure). Total $\mathrm{C}$ and $\mathrm{N}$ were determined using a LECO $\mathrm{CN}$ analyzer (LECO Instruments, Loveland, CO; Sparks 1996). Extractable P was determined using the Olsen $\mathrm{NaHCO}_{3}$ method (Olsen et al. 1954, Robertson et al. 1999). Gravimetric soil moisture content was determined using 75 -g subsamples that were oven-dried at $105^{\circ} \mathrm{C}$ to a constant weight. Dried soils were sieved, and rocks and roots $(>2 \mathrm{~mm})$ were weighed and subtracted from wet and dry soil weights to determine gravimetric soil moisture content of the fine fraction.

\section{Arthropod Communities}

Arthropods were collected along four 30-m transects inside and outside each exclosure using a sweep net once a month during the growing season (May, June, and July 2003). To ensure that no single area was swept twice, 1 pace separated each sweep for the entire 30-m transect (as in Baines et al. 1994) for approximately 20 sweeps per transect. Arthropods were collected between 1000 hours and 1500 hours and immediately placed into $70 \%$ ethanol until they were identified. Individuals were counted, identified to taxonomic order, and separated into morphospecies.

\section{Data Analyses}

We used a split-plot ANOVA design with a 2-way factorial to evaluate the fixed effects of site (whole plot factor with 4 levels: L.T. Murray Wildlife Area, Oak Creek Wildlife Area, Sinlahekin Wildlife Area, and Wenas Wildlife Area) and treatment (subplot factor with 2 levels: inside and outside the exclosure) on the following response variables: percent plant cover (e.g., total cover, cover by life form, and total woody cover), plant species richness, vegetation height, percent soil moisture, soil extractable $\mathrm{P}$, soil $\mathrm{C}: \mathrm{N}$ ratio, net $\mathrm{N}$ mineralization and nitrification rate of soils, and arthropod 
morphospecies, orders, and abundance. Quadrats within each treatment were averaged prior to statistical analysis. To meet assumptions of normality and homogeneity of variance, vegetation heights and soil C:N ratios were log-transformed, and mean percent cover, tree cover, tree with shrub cover, and grass cover were arcsine square-root transformed.

Comparisons of means were used to clarify interaction effects. A Tukey-Kramer adjustment was used for this assessment to decrease experiment-wise Type I errors. Due to the conservative nature of the Tukey-Kramer interaction analyses, $P$-values $<0.10$ were considered significant. Model assumptions of normality and homogeneity of variance were examined using Kolmogorov-Smirnov tests and graphical analysis of residuals. ANOVA calculations were obtained using PROC MIXED in SAS/STAT version 9.0 for Windows (SAS Institute, Inc., Cary, NC).

Biomass data were initially recorded on an ordinal scale from 0 to 6 in increments of 0.5 ; however, the data recorded on this scale could not be analyzed using ANOVA because assumptions of normality and homogeneity of variance were clearly violated. Consequently, differences in the distribution of quadrat data across categories inside and outside exclosures at the 4 sites were assessed using log-linear models. In addition, a single cross-tabulation of counts was constructed for each site without regard for different exclosures at a site. Loglinear models were fit using PROC CATMOD in SAS for Windows release 9.1.2.

\section{REsults}

\section{Vegetation}

At Sinlahekin, total plant cover and total native plant cover were greater inside the exclosures than outside the exclosures (Table 2). Sinlahekin also had a greater percentage of both shrub and tree cover and a lower percentage of bare soil inside the exclosures than outside the exclosures (Table 2). Oak Creek was found to have greater plant heights inside the exclosures compared to outside the exclosures (Table 2). In contrast, the L.T. Murray Wildlife Area showed a greater percent cover of shrubs outside the exclosures than inside (Table 2).

Oak Creek had a greater number of exotic species outside than inside the exclosures ค่ं

ศ ก ศ ค

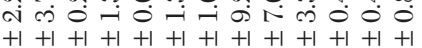

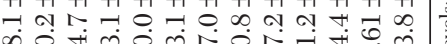

\& $\dot{\oplus}$ ஸे

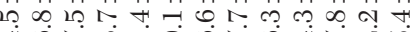

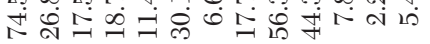

要

웅 웜

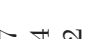
\%

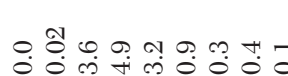

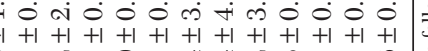
m 
(Table 2). Oak Creek also had a greater number of exotic species outside of the exclosures than Sinlahekin and L.T. Murray Wildlife Areas (Tukey-Kramer: $P<0.10$ ). All 4 sites had more exotic species outside the exclosures than inside the exclosures (Table 2).

For the biomass categories, a standard, saturated, 3-way log-linear model fit to the data indicated that the 4 sites did not share a common distribution $\left(G^{2}=11.28\right.$, df $=3, P=$ $0.01)$. To clarify the nature of the 3 -way interaction, the saturated log-linear model was reparameterized to incorporate separate treatment-by-biomass interactions for each site (“nested-by-value effects"; Stokes et al. 1995). At Sinlahekin, the distribution of biomass differs between treatments because biomass levels outside exclosures tend to be lower than biomass levels inside exclosures $\left(G^{2}=19.58\right.$, $\mathrm{df}=8, P=0.01)$. There was no evidence of biomass distribution differences inside and outside exclosures for either L.T. Murray $\left(G^{2}\right.$ $=9.48, \mathrm{df}=8, P=0.30)$, Oak Creek $\left(G^{2}=\right.$ 3.41, df $=8, P=0.91)$, or Wenas $\left(G^{2}=4.05\right.$, $\mathrm{df}=4, P=0.40)$ Wildlife Areas.

\section{Soil Properties}

Net $\mathrm{N}$ mineralization and net nitrification rates were greater outside than inside exclosures when measured across sites (Fig. 1A, 1B). Net nitrification was greater outside of the Oak Creek exclosures than inside (Fig. 1B). Oak Creek also had greater extractable P outside of the exclosures (Fig. 2A). Exclosure treatments did not affect C:N ratios (Fig. 2B). There was greater soil moisture in the top 15 $\mathrm{cm}$ of soil inside the exclosures than outside at Oak Creek, Sinlahekin, and Wenas (Fig. 2C) Wildlife Areas.

\section{Arthropod Communities}

We found no significant differences in arthropod abundance inside and outside the exclosures at any site during any sampling period (Table 3). We also found no significant differences in the number of morphospecies inside and outside the exclosures at any site during any sampling period, except for the June sampling period at Oak Creek, when there was a greater number of morphospecies found inside the exclosures than outside (Table 3).

In July, L.T. Murray Wildlife Area had a greater number of arthropod orders outside than inside exclosures (Table 3). In July, Oak

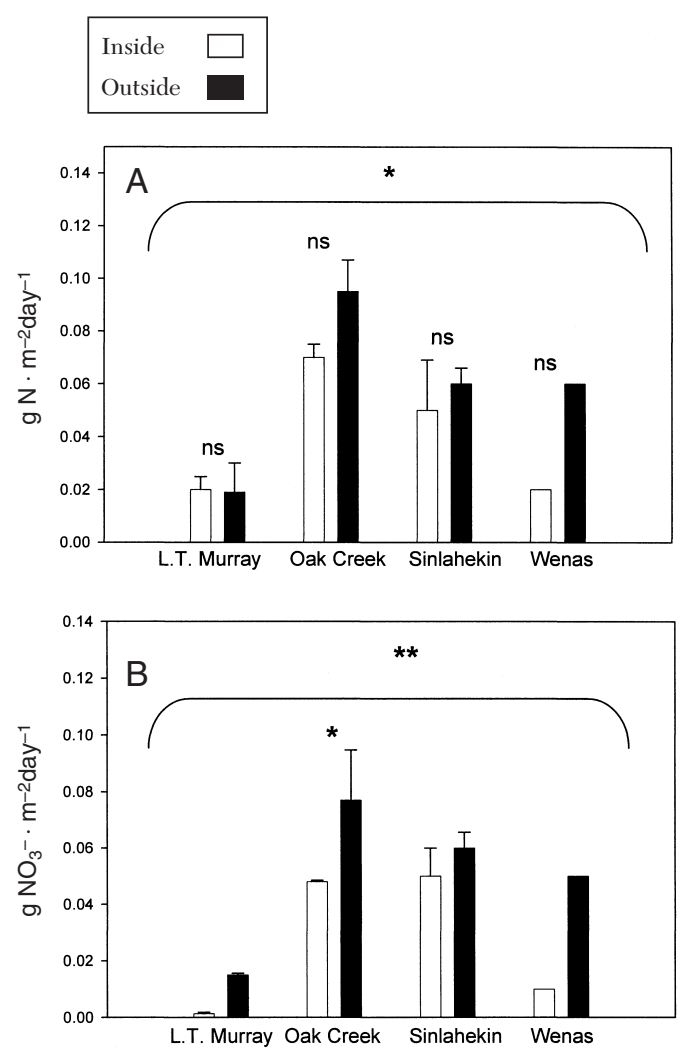

Fig. 1. (A) Mean nitrogen mineralization rates and (B) mean net nitrification measured across sites (* above bracket) and within sites (* under bracket) for inside and outside ungulate exclosures (where * is significant at $P<$ 0.1 and $* *$ is significant at $P<0.05)$ in L.T. Murray, Oak Creek, Sinlahekin, and Wenas Wildlife Areas, Washington. Bars represent 1 standard error.

Creek had a greater number of orders inside than outside the exclosures (Table 3). In May, the Sinlahekin Wildlife Area had a greater number of orders inside exclosures than outside, but in July, Sinlahekin had a greater number of orders outside than inside exclosures (Table 3).

\section{Discussion}

\section{Vegetation Structure and Composition}

The response of vegetation to 35 and 55 years of native ungulate grazing varied across sites. Aboveground biomass at Sinlahekin was greater inside the ungulate exclosures than outside, suggesting that vegetation at this site did not compensate for biomass losses to grazers. Conversely, at the Oak Creek site, it appears 

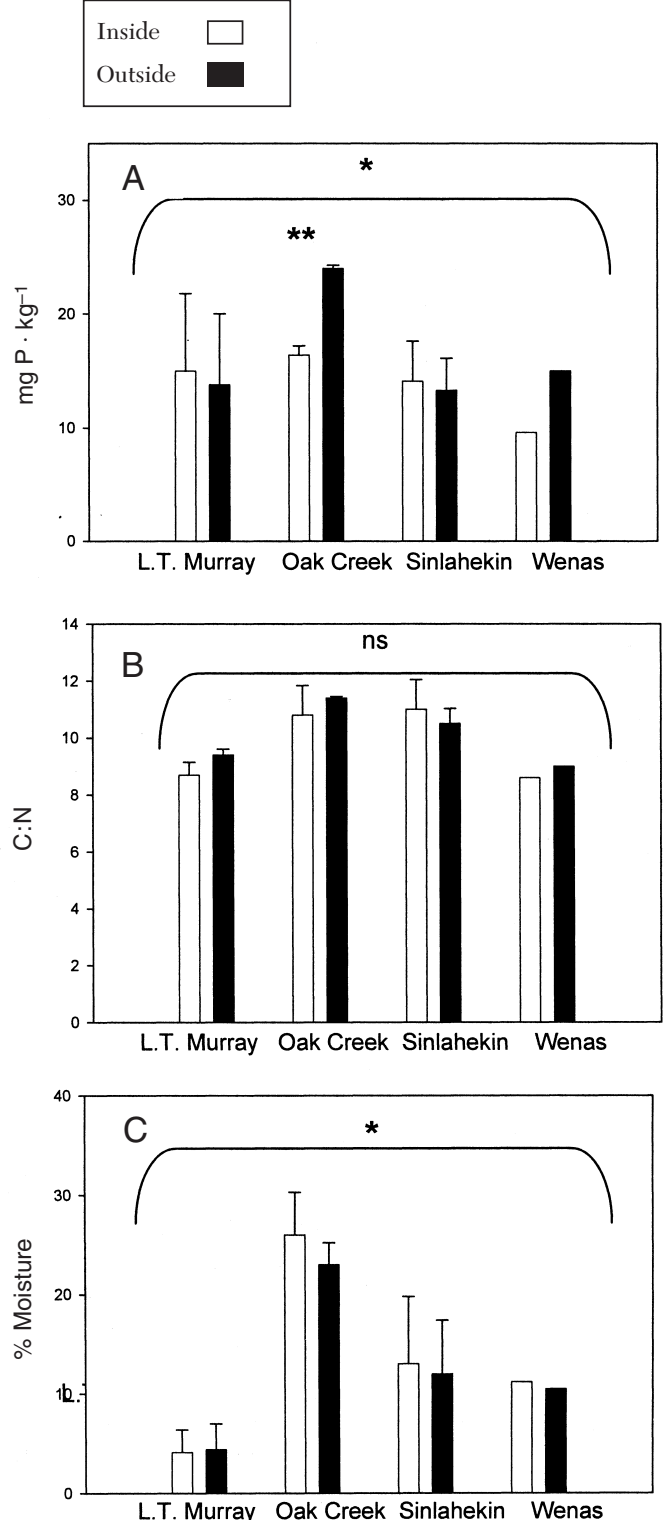

Fig. 2. (A) Mean extractable P, (B) mean C:N ratios, and (C) percent soil moisture measured across sites (* above bracket) and within sites (* under bracket) for inside and outside ungulate exclosures (where "ns" denotes no significance, * is significant at $P<0.05$, and ** is significant at $\mathrm{P}$ $<0.01)$ inside and outside ungulate exclosures in L.T. Murray, Oak Creek, Sinlahekin, and Wenas Wildlife Areas, Washington. Bars represent 1 standard error.

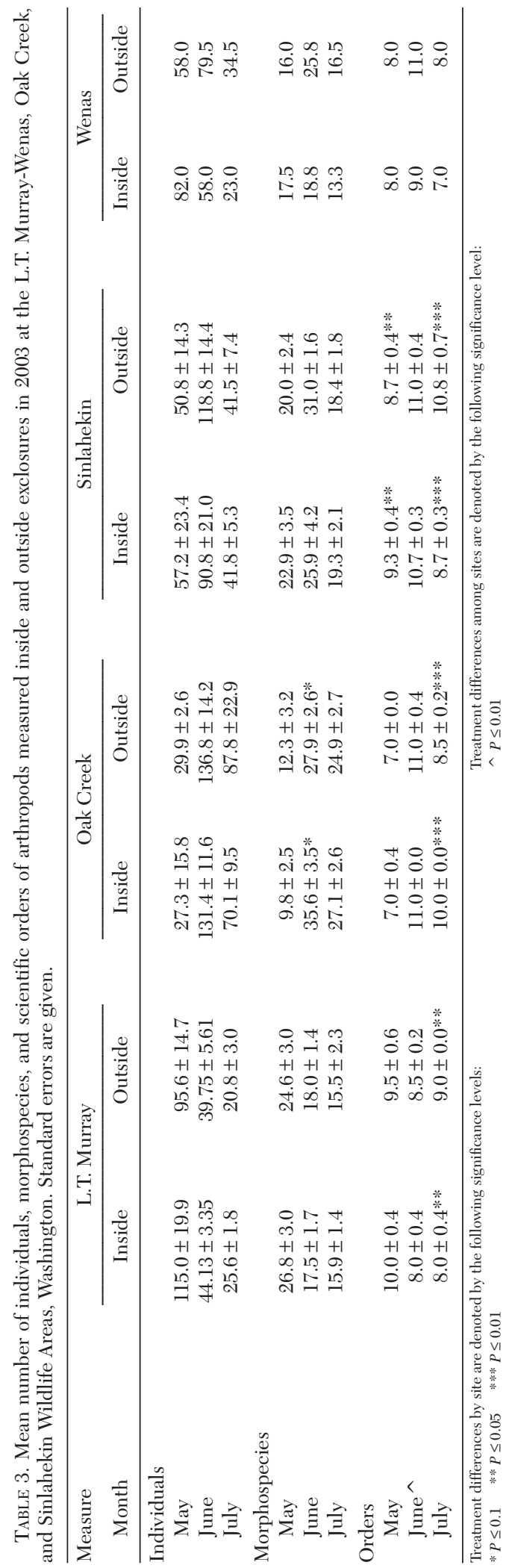


that plants had a compensatory response equal to vegetation loss, because ungulates had no effect on any vegetation measure other than height. Shrub cover at the L.T. Murray site was greater outside exclosures than inside, suggesting that vegetation at this site compensated or even weakly overcompensated for biomass losses to grazers.

This study did not examine each of the mechanisms that cause compensatory growth, although across sites we observed an increase in soil nutrient availability outside relative to inside the exclosures. Thus, presence of ungulates apparently increased soil nutrient availability, which could be expected to increase plant growth. This indirect positive fertilization effect was obvious at the low ungulate density site, but was less obvious at the high ungulate density site. At Sinlahekin the direct negative effects of ungulate grazing appeared to outweigh the indirect positive effects of fertilization.

These feedbacks could have been amplified by physiological responses of plants. For example, high rates of defoliation are expected to increase plant defenses at the expense of plant growth (DeMazancourt 2001). Because vegetation at the L.T. Murray site is defoliated to a much lesser degree, defense mechanisms are less crucial for plant survival, and increases in nutrient cycling and additions can be more efficiently utilized for growth (DeMazancourt 2001). Alternatively, grazing could have provided a selective advantage to woody plant growth, resulting in larger standing biomass in grazed plots.

Exotic species are often positively associated with disturbance (Milchunas and Lauenroth 1993, Walters and Martin 2003). Similar to other studies on the effect of ungulates facilitating plant invasion (Kimball and Schiffman 2003, Walters and Martin 2003), we found that exotic richness was greater outside the exclosures than inside at all 4 sites. However, identifying the mechanism behind this association is difficult because disturbances often simultaneously remove plant competitors (D’Antonio 1993), alter propagule pressure (Rouget and Richardson 2003), and increase resource availability (D’Antonio 1993).

\section{Soil Properties}

Across all study sites, we found that net $\mathrm{N}$ mineralization and nitrification rates were higher outside exclosures than inside. This suggests that the addition of concentrated and labile forms of $\mathrm{C}$ and $\mathrm{N}$ in ungulate urine and dung likely increased rates of $\mathrm{N}$ mineralization (Wardle 2002). We also found that soils were drier outside of exclosures across sites, which is interesting because in arid systems, net $\mathrm{N}$ mineralization and nitrification are expected to be faster in wetter soils (Paul and Clark 1996). Thus, we suggest that the presence of ungulates had a greater effect on $\mathrm{N}$ cycling than differences in soil moisture.

The addition of urine and dung to grazed soils may explain fast $\mathrm{N}$ cycling but does not provide an obvious explanation for reduced soil moisture in grazed soils. Reduced soil moisture could be explained by increased plant growth (evapotranspiration), which could be explained by increased $\mathrm{N}$ or $\mathrm{P}$ availability. It appears, then, that grazing-induced increases in plant productivity increased plant demand for soil water. Grazers, through the addition of concentrated forms of labile wastes, were able to overcompensate for plant demand for $\mathrm{N}$, but not for water. Grazing may have also induced the production of relatively labile plant materials, resulting in faster $\mathrm{N}$ cycling rates (Olofsson and Oksanen 2002). This, however, does not provide a likely explanation for the increased net $\mathrm{N}$ mineralization in our system because no differences in soil C: $\mathrm{N}$ ratios were found inside and outside exclosures, and this would not explain the decreases in soil moisture (Frank and Groffman 1998).

Oak Creek had a greater amount of extractable $\mathrm{P}$ outside the exclosures compared to inside. This likely resulted from the deposition of eliminated wastes, which adds slow-to-mineralize organic P (Whitehead 2000). Grazing and the elimination of waste are expected to return $\mathrm{P}$ to soils faster than plant senescence and decomposition (Whitehead 2000). However, the lack of treatment differences at the L.T. Murray and Sinlahekin sites fails to support this hypothesis.

\section{Arthropod Abundance,} Orders, and Morphospecies

If arthropod abundance had increased inside exclosures, then the potential would have existed for arthropods to replace ungulate effects. Because arthropod abundance did not increase inside exclosures at any site for any sampling 
period, arthropods do not appear able to functionally replace ungulates. It is possible that arthropod abundance did not differ between treatments but that productivity did. However, this condition is unlikely because arthropod growth rates are strongly dependent on temperature, and temperature was not influenced by the exclosures. Thus, it appears that ungulates, not arthropods, determined vegetation and soil differences found at each site from exclosures.

Another potential explanation of our results is that we had insufficient sampling to detect an arthropod abundance difference inside and outside of exclosures. Arthropod data are notorious for having large standard errors (Robinson 1998), and we found large differences by month. However, because our results reflect what has been found in previous studies, we believe our sampling was sufficient (e.g. Baines et al 1994, Rambo and Faeth 1999). In addition, we recognize that because this study was conducted for only 1 year, it may be difficult to extrapolate our invertebrate sampling to longer periods of time.

There was no clear relationship between arthropod diversity and exotic plant species richness. However, arthropod diversity did appear to respond to vegetation changes induced by ungulates. The number of scientific orders and morphospecies increased with percent plant cover and aboveground biomass. The relationships we found support the hypothesis that arthropod diversity will increase with plant biomass (Rambo and Faeth 1999).

\section{Future Directions}

There were differences across sites in this study that make cross-site comparisons difficult. For example, most of the study sites supported populations of elk; however, 1 study site (Sinlahekin) supported populations of deer. Some of the differences only observed at Sinlahekin could be a result of this difference.

Many studies have shown that mule deer diets contain predominantly forbs in spring and summer and browse in winter (Cowan 1947, Hansen and Reid 1970, Mackie 1970, Hobbs et al. 1983, Singer and Norland 1994). Though elk diets also contain significant amounts of forbs in early spring (Nelson and Leege 1982, Brown 1990), grass is the predominant component throughout much of the year (Nelson and Leege 1982). Thus the exclo- sure-induced differences in the shrub and tree layer observed in the Sinlahekin Wildlife Area could be a result of deer preference for this forage type. However, there were no trees at 2 of the other sites; therefore, it is difficult to speculate on how the different ungulate species might have had different effects on vegetation at the different sites.

In addition to the difference between elk and deer at the study sites, there was a difference in ungulate densities and climatic conditions. For example, Sinlahekin had greater ungulate densities than the other study sites; thus, the impact of ungulates might have been expected to be greater at this site. Sinlahekin was also at the highest latitude and had the greatest amount of annual precipitation, the lowest mean annual temperatures, and the greatest aboveground plant biomass inside the exclosures. On the other hand, L.T. Murray Wildlife Area had the lowest ungulate densities, the highest mean annual temperatures, and the lowest aboveground plant biomass inside the exclosures. These differences would be expected to support a different vegetative community as well as different densities of ungulates.

We know that native ungulates do not exist in a homogenous environment and their effects on vegetation are likely to vary across productivity gradients (Milchunas and Lauenroth 1993, Osem et al. 2004, Pakeman 2004). Not only are ungulate effects likely to vary as a function of site productivity, but effects are likely to vary as a function of the ungulate species and ungulate density, which in turn may vary as a function of site productivity - with different or more ungulates in areas that are more productive (Bender et al. 1997, Bauer 1990). However, little field data exist to determine whether these interdependent factors stabilize productivity across environmental gradients over the long term in shrubsteppe ecosystems. Crosssite comparisons are difficult with our particular dataset and with many others because of confounding variables such as ungulate species, climate, and elevation. We believe that future research should focus on determining how gradients of productivity in shrubsteppe ecosystems influence ungulate densities as well as site productivity. Only with cross-site comparisons will we gain increased insight into general patterns about the relationships between native ungulates and vegetation. 


\section{ACKNOWLEDGMENTS}

This work was supported by the Jack $H$. Berryman Institute of Utah State University, by USDA-NRICGP Biology of Weedy and Invasive Plants (\#35320-13473), and by the Utah Agricultural Experiment Station, Utah State University, Logan. It was approved as journal paper no. 7694. We thank John McGowan and Dale Swedberg, managers of the Oak Creek and Sinlahekin Wildlife Areas, respectively; Susan Durham for her statistical expertise and advice; Edd Bracken, Wayne Hunt, and Doug Kuehn for their help in collecting additional project information; Kara Davis and Page Kyle for their assistance in the field and laboratory; and the Washington Department of Fish and Wildlife for use of their wildlife areas.

\section{Literature Cited}

Baines, D., R.B. Sage, And M.M. Baines. 1994. The implications of red deer grazing to ground vegetation and invertebrate communities of Scottish native pinewoods. Journal of Applied Ecology 31:776-783.

BAUER, J.J. 1990. The analysis of plant-herbivore interactions between ungulates and vegetation on alpine grasslands in the Himalayan region of Nepal. Vegetatio 90:15-34.

Bender, L.C., D.L. Minnis, And J.B. Haufler. 1997. Wildlife responses to thinning red pine. Northern Journal of Applied Forestry 14:141-146.

Brown, R.E. 1990. Effects of a Savory grazing method on big game. Arizona Game and Fish Department, Technical Report 3:33.

Cowan, I. 1947. Range competition between mule deer, bighorn sheep and elk in Jasper Park, Alberta. Transactions of the North American Wildlife Conference 12:223-227.

D’Antonio, C.M. 1993. Mechanisms controlling invasion of coastal plant communities by the alien succulent Carpobrotus edulis. Ecology 74:83-95.

DeMazancourt, C., M. Loreau, and U. Dieckmann. 2001. Can the evolution of plant defense lead to plant-herbivore mutualism? American Naturalist 158:109-123.

Frank, D.A., and P.M. Groffman. 1998. Ungulate vs. landscape control of soil $\mathrm{C}$ and $\mathrm{N}$ processes in grasslands of Yellowstone National Park. Ecology 79: 2229-2241.

Hansen, R.M., AND L.D. REID. 1970. Diet overlap of deer, elk and cattle in southern Colorado. Journal of Range Management 28:43-47.

HaYdock, K.P., AND N.H. SHaw. 1975. The comparative yield method for estimating the dry matter yield of pasture. Australian Journal of Experimental Agriculture and Animal Husbandry 15:663-670.

Hobbs, N.T. 1996. Modification of ecosystems by ungulates. Journal of Wildlife Management 60:695-713.

Hobbs, N.T., D.L. BaKer, and R.B. GILL. 1983. Comparative nutritional ecology of montane ungulates during winter. Journal of Wildlife Management 47:1-15.
Johnson, L.C., AND J.R. MatchetT. 2001. Fire and grazing regulate belowground processes in tallgrass prairie. Ecology 82:3377-3389.

Kimball, S., And P.M. Schiffman. 2003. Differing effects of cattle grazing on native and alien plants. Conservation Biology 17:1681-1693.

LaWton, J.H., AND D.R. STRONG. 1981. Community patterns and competition in folivorous insects. American Naturalist 118:317-338.

Mackie, R.J. 1970. Range ecology and relations of mule deer, elk and cattle in the Missouri River breaks. Montana Wildlife Monographs 20:1-19.

Milchunas, D.G., And W.K. Lauenroth. 1993. Quantitative effects of grazing on vegetation and soils over a global range of environments. Ecological Monographs 63:327-366.

Milchunas, D.G., O.E. Sala, and W.K. Lauenroth. 1988. A generalized model of the effects of grazing by large herbivores on grassland community structure. American Naturalist 132:87-106.

Nelson, J.R., AND T.A. LeEge. 1982. Nutritional requirements and food habits. Pages 323-368 in J.W. Thomas and D.E. Toweill, editors, Elk of North America: ecology and management. Stackpole Books, Harrisburg, PA.

Olofsson, J., and L. Oksanen. 2002. Role of litter decomposition for the increased primary production in areas heavily grazed by reindeer: a litterbag experiment. Oikos 96:507-515.

Olsen, S.R., C.V. Cole, F.S. Watanabe, and L.A. Dean. 1954. Estimation of available phosphorus in soils by extraction with sodium bicarbonate. United States Department of Agriculture Circular No. 939, Washington, DC.

Osem, Y., A. Perevolotsky, and J. Kigel. 2004. Site productivity and plant size explain the response of annual species to grazing exclusion in the Mediterranean semi-arid rangeland. Journal of Ecology 92: 297-309.

Pakeman, R.J. 2004. Consistency of plant species and trait responses to grazing along a productivity gradient: a multi-site analysis. Journal of Ecology 92:893-905.

Paul, E.A., and FE. Clark. 1996. Soil microbiology and biochemistry. 2nd edition. Academic Press, San Diego, CA.

Porter, W.F., ANd H.B. Underwood. 1999. Of elephants and blind men: deer management in the U.S. National Parks. Ecological Applications 9:3-9.

RAmbO, J.L., AND S.H. FAETH. 1999. Effect of vertebrate grazing on plant and insect community structure. Conservation Biology 13:1047-1054.

Robertson, P.G., D.C. Coleman, C.S. Bledsoe, and P. SOLLins, EDITORS. 1999. Standard soil methods for long-term ecological research. Oxford University Press, Oxford, U.K.

RobINSON, S.K. 1998. Another threat posed by forest fragmentation: reduced food supply. Auk 115:1-3.

Rouget, M., AND D.M. Richardson. 2003. Inferring process from pattern in plant invasions: a semimechanistic model incorporating propagule pressures and environmental factors. American Naturalist 162:713724.

Samways, M.J., P.M. Caldwell, and R. Osborn. 1996. Ground-living invertebrate assemblages in native, planted and invasive vegetation in South Africa. Agriculture, Ecosystems and Environment 59:19-32. 
Semmartin, M., M.R. Aguiar, R.A. Distel, A.S. Moretto, AND C.M. GHERSA. 2004. Litter quality and nutrient cycling affected by grazing-induced species replacements along a precipitation gradient. Oikos 107:148160.

Singer, FJ., AND J.E. Norland. 1994. Niche relationships within a guild of ungulate species in Yellowstone National Park, Wyoming, following release from artificial controls. Canadian Journal of Zoology 72:13831394.

Sparks, D.L. 1996. Methods of soil analysis, chemical methods part 3. Soil Science Society of America, Inc. American Society of Agronomy, Inc., Madison, WI.

Stewart, A.J.A. 2001. The impact of deer on lowland woodland invertebrates: a review of the evidence and priorities for future research. Forestry 74:259270 .

Stokes, M.E., C.S. Davis, AND G.G. Koch. 1995. Categorical data analysis using the SAS system. SAS Institute, Inc., Cary, NC.

Tracy, B.F., AND D.A. Frank. 1998. Herbivore influence on soil microbial biomass and nitrogen mineraliza- tion in a northern grassland ecosystem: Yellowstone National Park. Oecologia 114:556-562.

Walters, C.M., and M.C. Martin. 2003. An examination of the effects of grazing on vegetative and soil parameters in the tall grass prairie. Transactions of the Kansas Academy of Science 106:59-70.

WardLE, D.A. 2002. Communities and ecosystems: linking the aboveground and belowground components. Princeton University Press, Princeton, NJ.

[WRCC] Western Regional Climate Center. 2004. General climate summary. Desert Research Institute, Reno, Nevada. Available from: http://www.wrcc.dri. edu/html

Whitehead, D.C. 2000. Nutrient elements in grassland: soil-plant-animal relationships. CABI Publishing, Wallingford, U.K.

Received 20 April 2005 Accepted 26 April 2006 